\title{
Choline-Phosphate Cytidylyltransferase A
}

National Cancer Institute

\section{Source}

National Cancer Institute. Choline-Phosphate Cytidylyltransferase A. NCI Thesaurus. Code C104957.

Choline-phosphate cytidylyltransferase A (367 aa, $\sim 42 \mathrm{kDa}$ ) is encoded by the human PCYT1A gene. This protein is involved in the biosynthesis of phosphatidylcholine. 